\title{
Bacteria and Inflammatory Cells in Fetal Membranes Do Not Always Cause Preterm Labor
}

\author{
JENNIFER H. STEEL, SOTIRIS MALATOS, NIGEL KENNEA, A. DAVID EDWARDS, \\ LYNDA MILES, PHILIP DUGGAN, PETER R. REYNOLDS, ROBERT G. FELDMAN, AND \\ MARK H.F. SULLIVAN
}

\begin{abstract}
Department of Obstetrics \& Gynaecology [J.H.S., S.M., L.M., M.H.F.S.], Wolfson and Weston Research Centre for Family Health, Institute of Reproductive and Developmental Biology, London W12 ONN, United Kingdom; Department of Paediatrics [N.K., A.D.E., P.D., P.R.R., R.G.F.], and MRC Clinical Sciences Centre [A.D.E.], Imperial College London, Hammersmith Hospital, London W12 ONN, United Kingdom; and Vmax Ltd. [R.G.F.], Winnersh Triangle, Wokingham, Berkshire RG41 5TU, United Kingdom
\end{abstract}

\begin{abstract}
ABSTR
Intrauterine infection has been frequently linked with preterm
labor before $30 \mathrm{wk}$ of human pregnancy. Many different species
of organisms have been detected, leading to the suggestion that
infection-induced preterm labor is a generic inflammatory re-
sponse to organisms rather than a specific response to a limited
number of pathogens. The detection of organisms by microbio-
logical culture is a laborious and unreliable process, so the aim of
this study was to harness modern molecular techniques to detect
organisms in tissues from human pregnancy. A DNA probe
specific for conserved regions of bacterial 16S ribosomal RNA
sequence was designed and labeled with fluorescein for fluores-
cence in situ hybridization. Organisms were detected in the great
majority ( $>80 \%$ ) of fetal membranes after prolonged premature
rupture of the fetal membranes and after preterm labor, which
was consistent with previous data. Organisms were also detected
\end{abstract}
Human labor at all gestational ages involves an inflammatory response, being characterized by increased levels of prostaglandins and cytokines $(1,2)$. This inflammation is presumed to be initiated by physiological mediators, including corticotrophin-releasing hormone (3) or platelet-activating factor (4), or by pathological processes (5-7).

At 23-32 wk of pregnancy, preterm labor is most frequently associated with micro-organisms within the uterus (8). These organisms are thought to activate inflammatory responses within intrauterine tissues and cause the recruitment of leukocytes to the fetal membranes (chorioamnionitis) $(9,10)$. This is so thoroughly accepted that in some studies, chorioamnionitis

Received July 4, 2003; accepted July 1, 2004.

Correspondence: Dr. Mark H.F. Sullivan, Department of Obstetrics \& Gynaecology, Institute of Reproductive \& Developmental Biology, Imperial College London, Wolfson \& Weston Research Centre, Hammersmith Hospital, Du Cane Road, London W12 0NN; e-mail: mark.sullivan@imperial.ac.uk.

Action Research and WellBeing supported this study.

DOI: 10.1203/01.PDR.0000153869.96337.90 in fetal membranes after preterm delivery without labor and in term deliveries (with or without labour). Inflammatory cells were found frequently in the amnion or chorion of preterm fetal membranes but not in term tissues. Our primary finding is that fluorescence in situ hybridization is an appropriate method to detect organisms in human fetal membranes. In addition, our data show that bacteria may be present in fetal membranes without necessarily causing an inflammatory response, so the mere presence of bacteria may not be sufficient to cause preterm labor.

(Pediatr Res 57: 404-411, 2005)

\section{Abbreviations}

FISH, fluorescence in situ hybridization PPROM, prolonged premature rupture of membranes rRNA, ribosomal RNA has been used as being diagnostic of intrauterine infection, without determination of the presence of bacteria (11). However, the precise relation between the presence of bacteria and an inflammatory response has not been clearly defined. This is an important issue as it is not known whether the presence of bacteria always causes chorioamnionitis or whether chorioamnionitis is always linked to infection.

Many different organisms have been identified from intrauterine tissues after preterm labor using various sampling and culture techniques (12-14), but no clear pattern has emerged from these studies, so it has not been possible to implicate one particular organism or family of organisms as the main causes of preterm labor. Furthermore, it has not been proved that the bacteria present in the vagina are those that have caused chorioamnionitis in preterm labor. The precise relation between bacteria and inflammation thus is unclear.

Indeed, it is not certain whether bacteria are present inside the uterus in pregnancies that proceed to term. A few studies have addressed this question $(13,15-18)$, but there have been 
no recent rigorous investigations of this question. Some of these studies report chorioamnionitis, but the technology to identify bacteria was not available.

The primary problem is that an accurate and foolproof method for the detection of bacteria is needed. Microbiological culture is problematic, as many different methods are needed to identify bacteria, and some organisms cannot be cultured at all, so it is difficult to be confident that all organisms have been detected.

We have used molecular detection techniques to overcome these issues. The DNA coding for 16S ribosomal RNA (rRNA) is functionally conserved and present in all bacteria but not in eukaryotic cells and therefore is appropriate for a generic molecular approach to the localization of bacteria (19). Fluorescence in situ hybridization (FISH) targeted to the 16S rRNA has been used as a rapid method for identifying bacteria in environmental samples $(20,21)$ and has also been used to detect Helicobacter pylori and other bacteria in sections of gastrointestinal tissue (22-24). This target is effectively amplified because it is present in multiple copies within each bacterium, which means that it is possible to carry out in situ hybridization with high sensitivity, using FITC-labeled oligonucleotide probes to detect small numbers of bacteria.

FISH with a probe for a conserved region of 16S rRNA has allowed us to investigate the link between bacteria and chorioamnionitis by asking the following questions: first, how often are bacteria present in preterm and term tissues after delivery? Second, is the presence of bacteria within the pregnant uterus sufficient to cause intrauterine inflammation, systemic fetal inflammation, or preterm labor?

\section{METHODS}

This study was approved by the local ethics committee (Hammersmith, Queen Charlotte's \& Chelsea and Acton Hospitals Research Ethics Committee), and informed consent was obtained from the parents of the infants. The preterm deliveries were a cohort of 50 consecutive infants who were delivered at $\leq 32$ completed weeks of gestation in Hammersmith Hospital (Table 1). On the basis of the clinical data, we divided the population into three groups, namely patients with no evidence of preterm labor, patients in preterm labor, and patients in preterm labor with prolonged premature rupture of the fetal membranes (PPROM). Previous studies have established links between PPROM and intrauterine infection (25) and the inflammatory process of labor (26). The clinical characteristics of these three groups (PPROM, preterm labor without PPROM, and preterm delivery not in labor) are shown in Table 1. Chorioamnionitis was assessed by routine histology. There were no differences in the gestational age at delivery, fetal weights, or multiple pregnancy between the groups. The method of delivery and the incidence of preeclampsia and of histologic chorioamnionitis occurred as expected, such that all infants who were born without labor were delivered by cesarean section and did not show histologic chorioamnionitis. In the other groups, histologic chorioamnionitis and vaginal delivery were more common and preeclampsia was less common. It should be emphasized that all women delivered in the absence of preterm labor had preeclampsia (defined as a blood pressure of $140 / 90 \mathrm{~mm} \mathrm{Hg}$ or more, in conjunction with proteinuria of $2+$ by Dipstick or $0.5 \mathrm{~g} / \mathrm{d}$; both measurements repeated on at least two separate occasions).

Term fetal membranes $(n=52)$ were collected after normal vaginal delivery ( 26 patients) or after elective cesarean section (for breech presentation or after previous cesarean section; 26 patients) from singleton pregnancies. Pregnancies that were complicated by preeclampsia, fetal growth restriction, or prolonged labor were excluded from the term group in this study. The investigators who conducted the laboratory studies described below were not aware of the route of delivery or any clinical details of the patients.

Fetal blood. For assessing the systemic fetal inflammatory response, umbilical venous blood was taken shortly after delivery of preterm infants and anticoagulated with heparin. The sample was centrifuged at $2000 \times g$ to remove all cellular components, and the plasma was stored at $-80^{\circ} \mathrm{C}$ until assay for cytokines. Concentrations of IL- $1 \beta$, IL-6, IL-10 and tumor necrosis factor- $\alpha$ were determined using high-sensitivity ELISA kits (Amersham Pharmacia Biotech), according to the manufacturer's instructions. The fetal blood cytokines were compared by ANOVA (Statview 4.5). The distribution of these data was inspected for normality, and it was found that the concentrations of all cytokines were not normally distributed, so these were log-transformed before analysis.

Tissues. Samples of fetal membrane $\left(\sim 5 \mathrm{~cm}^{2}\right)$ were collected and placed in fixative (10\% neutral buffered formalin) within $30 \mathrm{~min}$ to minimize bacterial growth after delivery. After fixing for $\sim 24 \mathrm{~h}$, tissues were rinsed and stored in $70 \%$ ethanol. Tissues were cut into small pieces $\left(\sim 1 \mathrm{~cm}^{2}\right)$, dehydrated through ascending ethanols, and embedded in paraffin wax.

Probes. The probes were based on those used previously by Greisen et al. (27) and were confirmed to be generic for bacterial 16S rRNA by Blast search of on-line databases of sequences. Oligonucleotide probes were custom made (GIBCO), end-labeled with one molecule of fluorescein-isothiocyanate per probe molecule. The bacterial probe sequences were as follows: antisense 5'-F-ACTGCTGCCTCCCGTAGGAGTTTATTCCTT-3' and sense 5'-F-AAGGAATAAACTCCTACGGCAGGCAGCAGT-3'.

In situ hybridization. Paraffin sections $(5 \mu \mathrm{M})$ were cut using a sterile approach, using a water bath cleaned thoroughly before use and filled with fresh distilled water. Gloves were worn, and the microtome knife was thoroughly disinfected by lipsol and ethanol before use. Sections were mounted on poly-L-lysine-coated clean glass slides that were dried at $37^{\circ} \mathrm{C}$ for a few hours then stored to avoid contamination by dust. Sections from each block were dewaxed and digested with $10 \mu \mathrm{g} / \mathrm{mL}$ of proteinase $\mathrm{K}$ (Sigma Chemical Co.) in PBS that contained $1 \mathrm{mM}$ EDTA at $37^{\circ} \mathrm{C}$ for $10 \mathrm{~min}$. Digestion was halted by incubating slides in $0.2 \%$ glycine in PBS for $5 \mathrm{~min}$, then slides were fixed in neutral buffered formalin for $2 \mathrm{~min}$. They were rinsed in PBS and then in autoclaved in distilled water and air-dried.

Sections from each specimen were hybridized with antisense and sense probes. Additional control sections received no probe (hybridization buffer only) to allow assessment of autofluorescence. The final probe concentration in hybridization buffer was $10 \mathrm{ng} / \mu \mathrm{L}$. Hybridization buffer contained $50 \%$ deionized formamide (Sigma Chemical Co.), $5 \times$ SSC, $10 \%$ dextran sulphate (Sigma Chemical Co.), $5 \times$ Denhardt's solution (Sigma Chemical Co.), and 100 $\mu \mathrm{g} / \mathrm{mL}$ denatured herring sperm DNA (Sigma Chemical Co.). Approximately $20-50 \mu \mathrm{L}$ of diluted probe was applied per section and covered with Parafilm coverslips (cut to correct size to cover section). Slides were incubated at $37^{\circ} \mathrm{C}$

Table 1. Summary of patient details

\begin{tabular}{|c|c|c|c|c|}
\hline & Cohort & PPROM & Preterm labor & PNIL \\
\hline$n$ & 50 & 22 & 15 & 13 \\
\hline Delivery method (vaginal, C-section) & 18,32 & 7,15 & 11,4 & 0,13 \\
\hline GA (wk) & $23.3-32.0$ & $23.5-31.3$ & $23.3-31.0$ & $25.4-32.0$ \\
\hline Preeclampsia* & $17(8 \ddagger)$ & $2(1)$ & $2(2 \ddagger)$ & $13(5)$ \\
\hline Chorioamnionitis $\dagger$ & $20 / 39$ & $14 / 16$ & $6 / 14$ & $0 / 9$ \\
\hline Multiple births & $\begin{array}{l}\text { triplets } \times 1 \\
\text { twins } \times 5\end{array}$ & triplets, twins & twins $\times 2$ & twins $\times 2$ \\
\hline
\end{tabular}

PNIL, preterm not in labor.

* Numbers with preeclampsia and intrauterine growth restriction.

$\dagger$ Data on chorioamnionitis were not available for all pregnancies.

$\ddagger$ One infant had intrauterine growth restriction in the absence of preeclampsia. 
overnight and oriented so that the slides were horizontal in slide boxes humidified with moist tissue paper soaked in distilled water. Coverslips were removed by soaking in $2 \times \mathrm{SSC}[0.3 \mathrm{M}$ of $\mathrm{NaCl}$ and $0.03 \mathrm{M}$ of Tris- $\mathrm{HCl}(\mathrm{pH}$ 7.0)], and the slides were rinsed in two changes of $2 \times$ SSC. Sections were mounted in Vectashield with DAPI to stain nuclei blue (Vector Laboratories) with glass coverslips and viewed under appropriate UV wavelength for FITC with a $\times 100$ oil immersion lens. Images were captured using a digital camera using three wavelengths for three color channels: red, green, and blue. A composite image was produced combining the three channels, in which nuclei appeared blue, FITC staining was green, and the background cells appeared red/brown/yellow. In negative control sections, some fluorescence from red blood cells or connective tissue fibers was seen, but this was present in both red and green channels, giving yellow in the final image, clearly different from the green of FITC. Organisms that were seen on the tissue surface (the edge of the section) or on the glass slide were disregarded because only organisms that were actually present deep within the tissue were taken to be endogenous to the tissue at the time of sampling.

Separate sections from each tissue were examined at least twice to ensure that the data obtained were representative; a high level of consistency was found between sections from each tissue. This includes tissues that had no bacteria detectable on both analyses, indicating that contamination during processing is unlikely to be a problem.

Immunohistochemistry for cell types. Tissue sections were stained with hematoxylin and eosin and assessed for evidence of chorioamnionitis; this was identified on the basis of gross inflammatory changes, particularly the visible presence of infiltrating cells or of tissue degradation.

To identify the infiltrating cells, the following MAbs were obtained from Novocastra Laboratories: CD45, leukocyte common antigen found on all leukocytes; CD3, T-lymphocyte $\epsilon$-chain of CD3; CD14, LPS receptor, found on cells of monocyte-macrophage lineage; CD16, Fc $\gamma \mathrm{RIII}$ receptor for $\mathrm{Fc}$ region of antibodies, found granulocytes/neutrophils, and some activated macrophages and NK cells; CD56, neural cell adhesion molecule natural killer cells and cell of neural origin; and cytokeratin 7 (CK7), trophoblast and epithelial marker. These were used to immunostain sections from each fetal membrane sample, using a Vector Elite ABC peroxidase kit and the method supplied by the manufacturer. Antigen retrieval was not required for cytokeratin 7 staining, but sections were heated in a microwave oven in $0.01 \mathrm{M}$ of citrate buffer for $10-20 \mathrm{~min}$ at $800 \mathrm{~W}$ before staining with $\mathrm{CD}$ marker antibodies. Stained sections were categorized according to the presence of positive cells and their location within the tissue.

Preliminary histology. Sections were cut from all fetal membranes to determine whether all three components of the fetal membranes (amnion, chorion, and decidua) were present. Most tissues delivered at term by cesarean section (before labor) were intact [22 of $26(85 \%)]$, whereas after term labor (vaginal delivery), fewer tissues were intact [16 of $26(62 \%)]$. Preterm tissues delivered by cesarean section (not in labor) were mainly intact [9 of $12(75 \%)]$. After preterm labor, $10(71.4 \%)$ of 14 were intact, whereas after PPROM, 10 $(45.5 \%)$ of 22 were intact. These findings indicate that PPROM as well as vaginal delivery affects fetal membrane integrity and that there is a need for all fetal membranes to be assessed rigorously, as tissue loss may affect any data obtained and could bias the conclusions drawn. Despite these concerns, we found that the detection of bacteria by FISH was unaffected by whether the membranes were intact and therefore show data from all tissues available. Intact membranes are needed for an accurate assessment of inflammatory cells by immunocytochemistry, and the data shown on cell types therefore refer only to the intact tissues in each group.

\section{RESULTS}

In situ hybridization for bacteria. Individual bacteria could be visualized with the green FITC fluorescence deep within preterm (Fig. $1 A-C$ ) and term tissues (Fig. $1 E$ and $F$ ). Sections that were hybridized with the sense probe showed no specific labeling (Fig. 1D). Different morphologic types of organisms were seen (Fig. 2). The majority of organisms were rodshaped, although these varied in size and shape (Fig. $2 A, B$, and $D)$. In some cases, more than one morphologic type was present in the same tissue section (Fig. 2C), and this was confirmed in repeat sections.

The numbers of tissues with bacteria present deep within the membranes are shown in Fig. 3. Organisms were present in the majority of samples studied, including those tissues delivered (a)

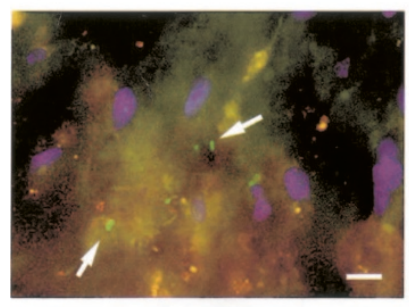

(c)
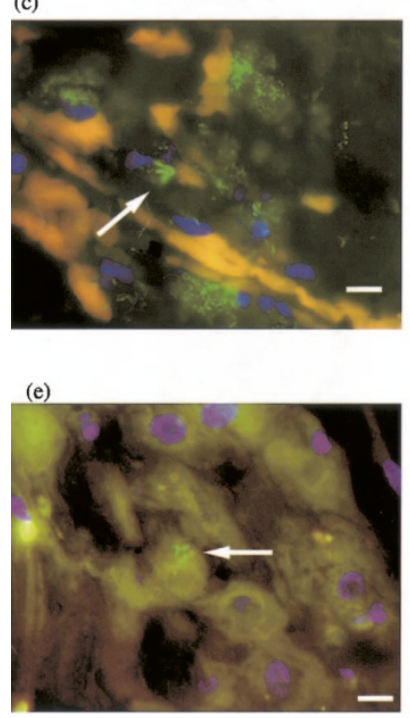

Figure 1. FISH with antisense $(A, B, C, E$, and $F$ ) or sense (control; $D$ ) probes for 16S rRNA. Samples were obtained from preterm $(A-D)$ and term $(E$ and $F)$ tissues. Arrows show typical positive fluorescence. Scale bar $=50 \mu$.

(a)

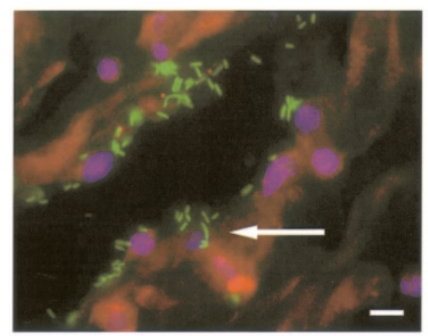

(c)

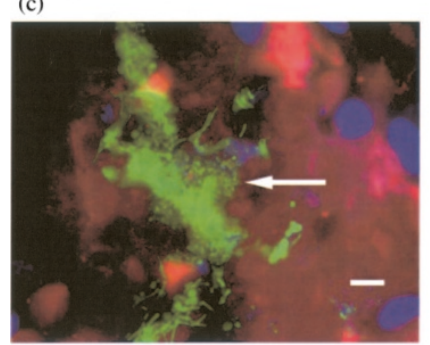

(b)

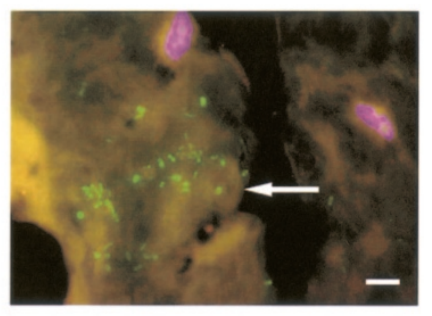

(d)

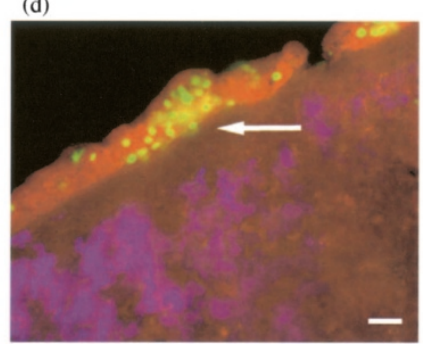

(b)
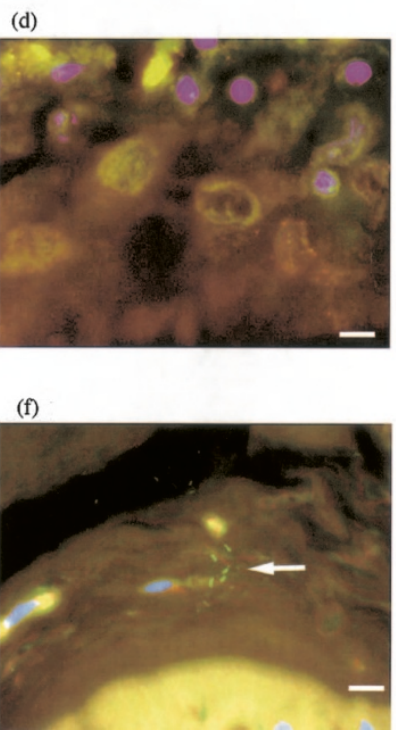

Figure 2. FISH with antisense probe for $16 \mathrm{~S}$ rRNA. Examples of different morphologic types of organisms are shown. Arrows show positive fluorescence. Scale bar $=5 \mu$.

by elective cesarean section at term (term not in labor group). Organisms were present in the great majority of preterm tissues, with no obvious differences related to the method of delivery (Fig. 3). 


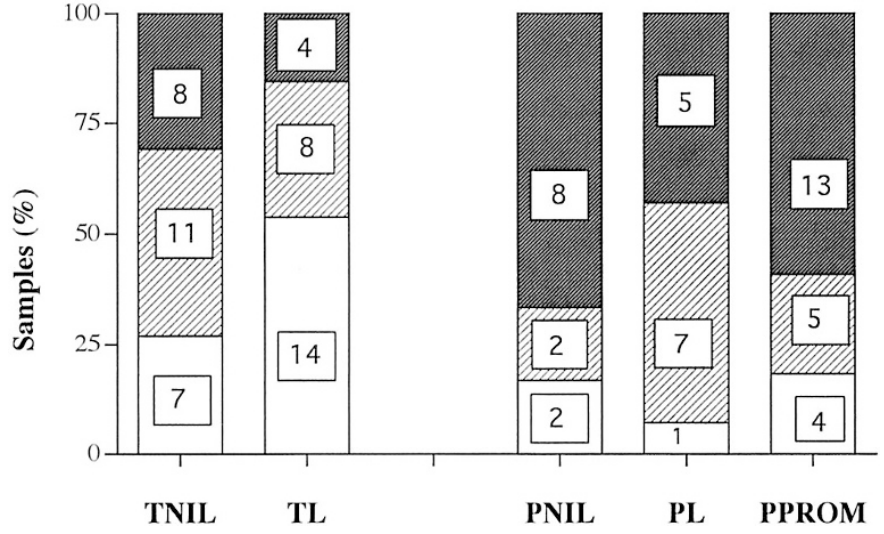

Figure 3. Percentages of fetal membranes from each of the five groups

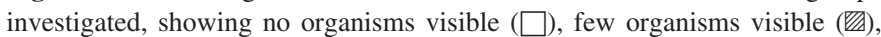
and many organisms visible (因). TNIL, term not in labor; TL, term labor; PNIL, preterm not in labor; PL, preterm labor. Percentages of each group are shown on the left axis, and actual tissue numbers are boxed within the columns.
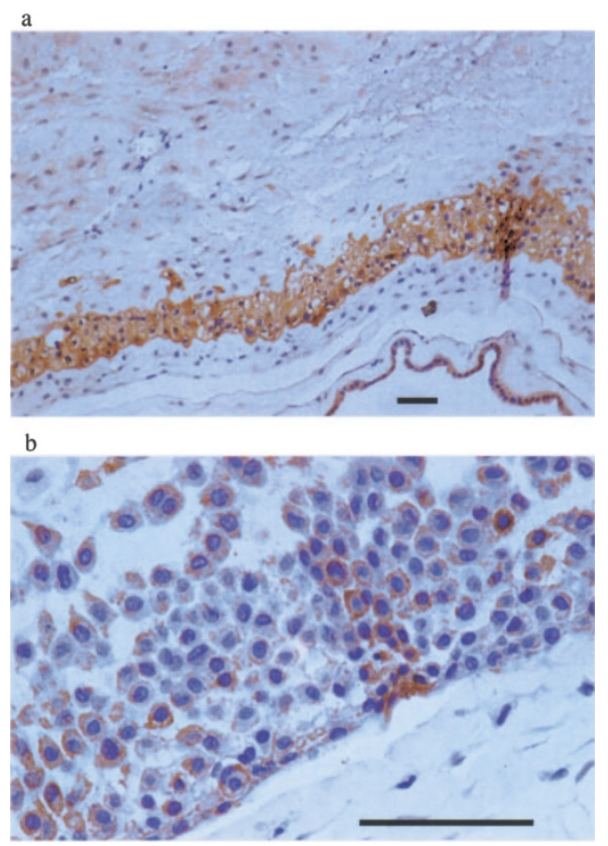

Figure 4. Immunohistochemistry for CK7 in term $(A)$ and preterm $(B)$ tissues. Positive cells are brown. Sale bar $=50 \mu$.

Immunocytochemistry for inflammatory cells. Chorion stained positive for CK7 (Fig. 4A), although in some samples, the intensity of staining was heterogeneous (Fig. 4B). The amniotic epithelium was also positive for CK7 in some samples (Fig. 4A), but the decidua did not stain with CK7 (Fig. 4), enabling clear identification of intact fetal membranes (amnion, chorion, and decidua present). Routine histopathologic assessment of these tissues (Table 1) indicated no inflammatory changes in term tissues or in any tissues after preterm cesarean delivery; $43 \%$ of tissues after preterm labor and $88 \%$ of tissues after PPROM showed chorioamnionitis, which is a statistically significant difference $(p<0.05)$.

Only intact fetal membranes (i.e. those with visible amnion, chorion, and decidua) were used for studies on the distribution
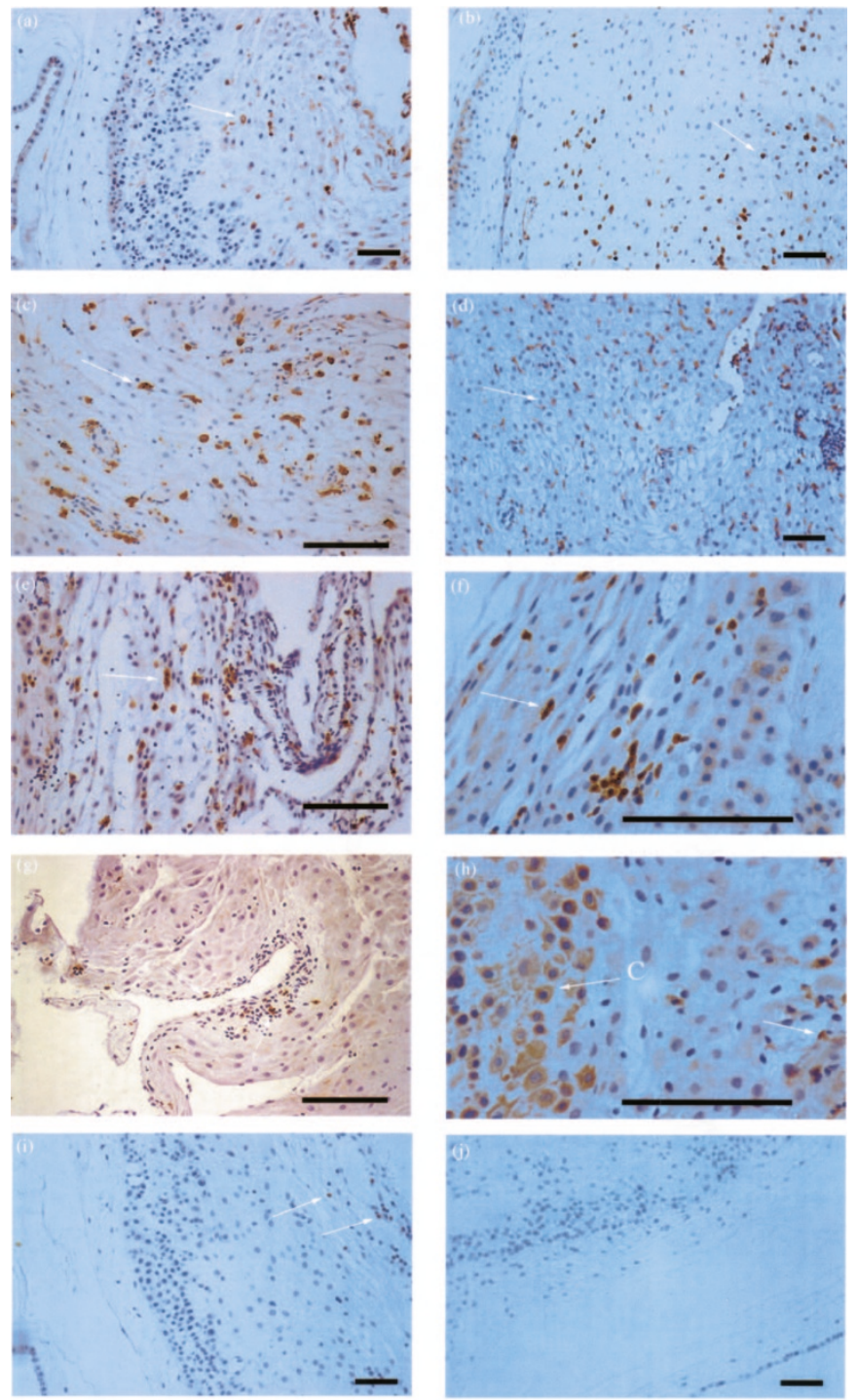

Figure 5. Immunohistochemistry for CD45 (leukocyte common antigen; $a$ and $b$ ), CD14 (monocytes and macrophages; $c$ and $d$ ), CD16 (neutrophils; $e$ and f), CD56 (natural killer cells; $g$ and $h$ ), CD3 (T-lymphocytes; $i$ ), and control antibody $(j)$. Tissues are from term $(a, c, e, g$, and $i)$ and preterm $(b, d, f, h$, and $j)$ samples. Magnification: $\times 100$ in $a, b, d, i$, and $j ; \times 200$ in $c, e$, and $g ; \times 400$ in $f$ and $h$. Positive cells are indicated with an arrow, and CD56+ cells in the chorion are indicated by C. Scale bar $=50 \mu$.

of CD-positive cells, and typical data are shown in Fig. 5. Each tissue section was assessed for the presence or absence of positive cells in amnion, chorion, or decidua, and these data are summarized in Fig. 6.

Term fetal membranes (Fig. 6) had very few positive cells in the amnion or chorion components of the membranes. The decidua in term tissues was positive for CD45 and CD16 in almost all samples, and smaller numbers of tissues were positive for CD14, CD56, and CD3.

Many preterm tissues had inflammatory cells within the amnion and chorion (Fig. 6), independent of the clinical pathology (preeclampsia, preterm labor, or PPROM). The overall pattern in preterm not in labor tissues and preterm labor tissues (Fig. 6) seem to be similar in that similar numbers of amnion and chorion were positive. Tissues obtained after PPROM (Fig. 

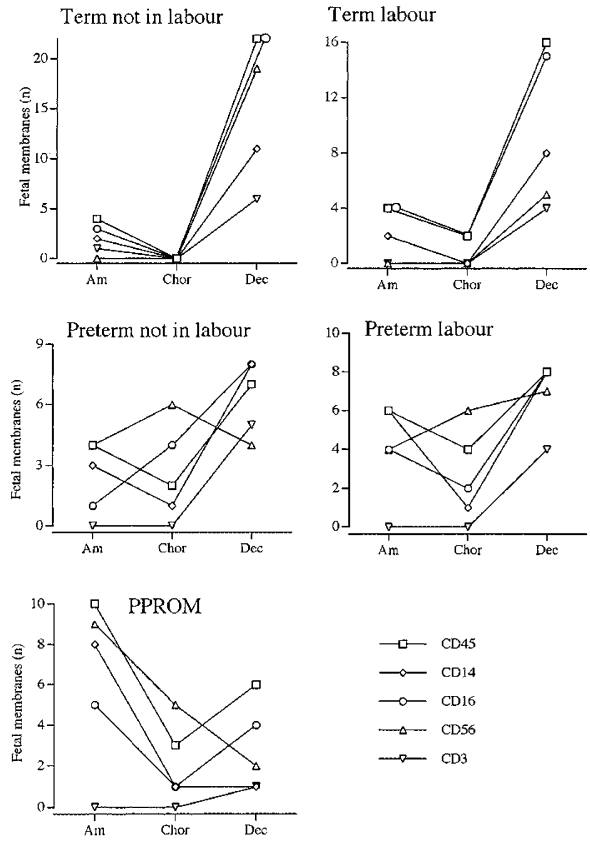

Figure 6. Localization of $\mathrm{CD}+$ cells in amnion, chorion, and decidua from each of the study groups. Numbers of membranes that contained cells that stained for the particular antigen are shown. Left axis of each graph indicates total number of samples in each group.
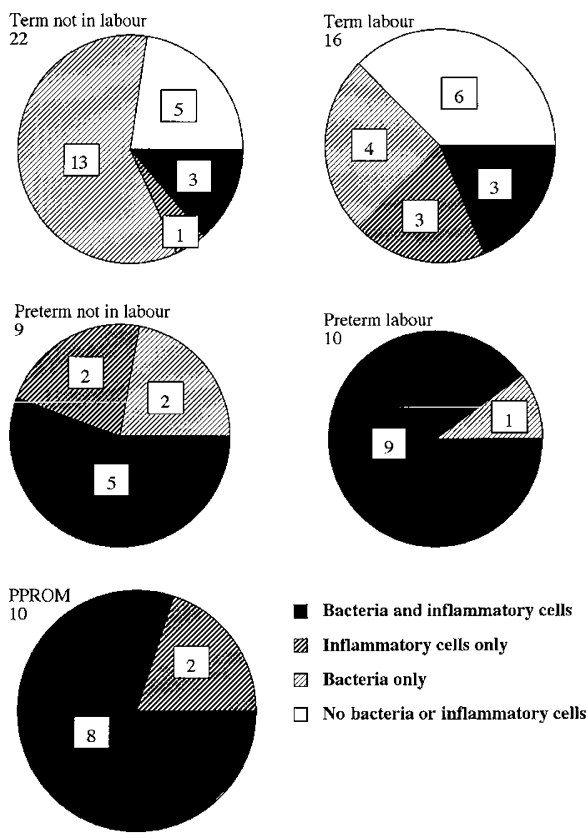

$\square$ No bacteria or inflammatory cells

Figure 7. Summary of the localization of inflammatory $(C D+)$ cells (in amnion or chorion) and of bacteria deep within intact fetal membranes. Numbers of tissues in each group are shown.

6) particularly had positive cells within the amnion, such that this exceeded the numbers of positive decidual samples. The cells present in preterm amnion or chorion were mainly $\mathrm{CD} 14+, \mathrm{CD} 16+$, or CD56+, suggesting that cells of monocyte, neutrophil, and NK lineages have moved into amnion and chorion.

Association between bacteria and inflammatory cells. The association between the presence of organisms deep within the fetal membranes and inflammatory cells visualized by immunohistochemistry for $\mathrm{CD}$ markers in the amnion or chorion is shown in Fig. 7. There was no clear association between bacteria and inflammation in term tissues. In term tissues delivered before labor, the majority of tissues contain organisms, but $<25 \%$ of the tissues show any inflammatory cells present. After term labor, more tissues contain inflammatory cells, but they are still a minority.

The preterm tissues showed that bacteria and inflammatory cells were present in the majority of tissues studied, but this was not related to pregnancy outcome. Approximately 50\% of preterm not in labor tissues contain organisms deep within the membranes and inflammatory cells in amnion or chorion, with the remainder having either organisms or inflammatory cells. Tissues obtained after preterm labor or after PPROM are mainly double-positive for bacteria deep within the membranes and for inflammatory cells in amnion or chorion.

Fetal systemic inflammatory response. The levels of cytokines in fetal plasma were determined (Table 2). Levels of IL- $1 \beta$ and IL- 6 were significantly elevated in plasma from the PPROM group compared with the preterm not in labor group. Plasma from preterm labor (without PPROM) had intermediate levels of both ILs, which did not differ from the PPROM or the preterm not in labor groups (Table 2). IL-10 levels were lower in the preterm labor and PPROM groups, with the levels of significance shown. Levels of tumor necrosis factor- $\alpha$ were low and did not differ between the groups. Histologic chorioamnionitis correlated with the high plasma cytokine levels in the PPROM group, but there was no correlation of the fetal plasma cytokine levels with detailed leukocyte analysis or bacteria in fetal membranes.

\section{DISCUSSION}

Detection of organisms. Unexpectedly, organisms could be detected deep within human fetal membranes by in situ hybridization at all stages of pregnancy (Figs. 1-3). Thorough precautions were taken at sample collection and through the laboratory stages to minimize contamination, and only tissue sections deep within the samples were studied, yet even tissue delivered by elective cesarean section at term had organisms present $(70 \%$ positive). These results cannot be explained by contamination during processing. Indeed, the data obtained may represent a minimum level of bacterial detection, as our total sample represents perhaps $1 \%$ of the fetal membrane.

Most preterm tissues contained bacteria, which is broadly consistent with many studies that have linked preterm labor or PPROM with intrauterine infection $(8,28-30)$. However, it must be pointed out that preterm tissues delivered by cesarean section without labor contain bacteria as frequently as those collected after preterm labor or PPROM. We conclude from these data that the presence of bacteria is common and insufficient to cause preterm labor or PPROM.

Infection and inflammation have previously been studied less stringently in term delivery tissues $(13,15-18)$. Not all of these studies directly studied bacteria, but two studies in particular are of interest. Dong et al. (13) found bacteria in 117 
Table 2. Summary of fetal plasma and fetal membrane data

\begin{tabular}{|c|c|c|c|c|c|c|c|}
\hline & IL-1 $\beta(\mathrm{pg} / \mathrm{mL})$ & IL-6 (pg/mL) & IL-10 (pg/mL) & $\begin{array}{l}\text { TNF- } \alpha \\
(\mathrm{pg} / \mathrm{mL})\end{array}$ & Chorioamnionitis & $\begin{array}{l}\text { Amnion/chorion } \\
\text { leukocytes }\end{array}$ & Bacteria \\
\hline PNIL $(n=13)$ & $1.1 \pm 0.2(12)$ & $187.6 \pm 174.8$ & $197.0 \pm 63.5$ & $0.48 \pm 0.07$ & $0 / 9$ & $7 / 9$ & $10 / 12$ \\
\hline $\mathrm{PL}(n=15)$ & $4.2 \pm 2.3(13)$ & $393.6 \pm 256.7$ & $69.7 \pm 27.7 *$ & $0.68 \pm 0.25$ & $6 / 14$ & $9 / 10$ & $13 / 14$ \\
\hline
\end{tabular}

Different assessments of an inflammatory response are shown. Cytokine levels were determined in fetal plasma. Fetal membranes were assessed by routine histology (chorioamnionitis), immunohistochemistry (amnion/chorion leukocytes), and FISH for 16S rRNA (bacteria). All data are means \pm SEM. Sample numbers are shown.

PL, preterm labor.

$* p<0.05$ vs PNIL.

$\dagger p=0.0521$ vs PNIL.

$\ddagger p=0.0676$ vs PNIL.

(95.1\%) of 123 amniotic fluid samples, and Gibbs et al. (17) showed that $30.8 \%$ of control and $80.6 \%$ of infected term patients had organisms within their amniotic fluid. This latter paper also showed that that "high virulence" infection was detected in $7.7 \%$ and $69.2 \%$ of the same patients, indicating that the nature of the organisms may be critical.

Previous studies have been hampered because a complete determination of the microbiology of fetal membranes has been difficult. Bacteria in tissue sections may be visualized by Gram staining or immunocytochemistry (31), but these methods are imprecise and relatively limited in scope. Microbiological culture would require multiple culture techniques for the many organisms that may be present $(13,18)$ and is inherently vulnerable to false-negative data, particularly as patients who are considered at risk for infection-induced preterm labor are often treated with antibiotics $(32,33)$. In contrast, in situ hybridization provides a simple method to determine whether organisms are present and will visualize damaged, dying, or dead bacteria, thus providing a more complete overview. The current data thus provide a novel insight, suggesting that the presence of bacteria within the uterus during pregnancy is common.

A further advantage of FISH is that it does not require live bacteria to succeed, whereas culture methods do. This is potentially important, as alterations in the vaginal bacterial flora, whereby the generally harmless lactobacilli are replaced by more pathogenic species (bacterial vaginosis), are considered one initiating factor for preterm labor $(29,30)$. Patients in whom bacterial vaginosis is detected may be treated with antibiotics, which can decrease the incidence of preterm labor $(32,33)$, but could also give false-negative data for bacterial culture.

Chorioamnionitis and specific inflammatory cells. Histologic chorioamnionitis requires major inflammatory changes in fetal membrane structure or cellular composition to be recognized $(34,35)$ and is often used as a surrogate marker for infection (11). We found it only in fetal membranes delivered after PPROM or preterm labor but not after preterm cesarean section (Table 1). In contrast, immunohistochemistry is a more sensitive technique (36) and can detect the infiltration of smaller numbers of leukocytes into the fetal membranes.

With this method, we could detect inflammatory cells $(\mathrm{CD} 45+)$ in almost all fetal membranes studied, independent of gestational age or labor. In term tissues, the majority of these cells were present in the decidua, as described previously (37). Term decidual cells were most commonly positive for CD16 (neutrophils) with fewer tissues containing CD56+ (NK cells), CD14 (monocyte/macrophage lineage), or CD3+ cells (Tlymphocytes). This distribution reflects previous data on leukocytes in term decidua (37). Few term tissues had any CD+ cells in amnion or chorion (Fig. 6).

Preterm tissues also had a high frequency of all four types of leukocytes in the decidua, thus resembling the term data. However, the amnion and chorion from preterm tissues commonly contained CD45+ cells; specific immunohistochemistry showed $\mathrm{CD} 14+, \mathrm{CD} 16+$, and CD56+ cells, indicating that that macrophages, neutrophils, and NK cells but not Tlymphocytes had infiltrated into amnion and chorion. This was particularly the case in tissues that were obtained after PPROM, in which $50 \%$ of the amnions were positive for all three markers.

The infiltration of leukocytes can readily be explained in cases of preterm labor or PPROM; it is less clear why inflammatory cells should be present in the amnion and chorion in the absence of preterm labor. However, these pregnancies were predominantly affected by severe preeclampsia, and recent work has shown that preeclampsia may be characterized as a maternal inflammatory syndrome that particularly affects the vascular system (38-40), and it may be that these inflammatory changes encourage the recruitment of leukocytes to the fetal membranes.

More preterm chorion tissues were positive for CD56 than for CD45 (Fig. 6). This was unexpected as all leukocytes express CD45 (leukocyte common antigen), and this suggests that these chorionic CD56+ cells may not be leukocytes. Visually, these CD56+ cells are larger than those seen in the adjacent decidua (Fig. 5h) and resemble the normal chorionic trophoblast (CK7+ cells; Fig. 4). We predict that these cells would be $\mathrm{CD} 45-\mathrm{CD} 56+\mathrm{CK} 7+$, but this needs to be proved by definitive analysis (e.g. fluorescence-activated cell sorting). CD56 is expressed by human trophectoderm (41), endovascular trophoblast $(42,43)$, and choriocarcinoma cells $(44)$, as well as by early trophoblast in mouse pregnancy (45) and by macaque trophoblast (46). None of these large CD56+ cells was found in the chorion of term fetal membranes. The presence of the large CD56+ cells in preterm tissues may be related to the reasons for early delivery, namely preeclampsia, preterm labor, or PPROM, and we cannot be sure whether normal preterm chorion would express CD56. This also applies to amniotic epithelium, which variably expressed CK7 and CD56; we anticipated that these markers would be present on 
trophoblast (47) and on NK cells (48), respectively, and the significance of this wider distribution is not clear.

Previous work has shown that the decidua of human term pregnancy commonly contains neutrophils and macrophages, with smaller numbers of NK cells and T-lymphocytes (37), and our data confirm this distribution of leukocytes (Fig. 6). Similar data were obtained from samples that were taken before or after preterm labor, but tissues that were obtained after PPROM had fewer CD + cells present in decidua (Fig. 6). The reasons for this decrease in $\mathrm{CD}+$ cells after PPROM are not clear, but we attribute this to damage to cell surface markers, as proteolytic enzymes released from activated leukocytes can decrease cell-surface levels of CD proteins $(49,50)$. Leukocyte activation has been implicated in infection-driven preterm labor in seven patients (51), but the role of this process in our patients requires further study.

Bacteria and inflammatory cell types. The relationship between the presence of bacteria deep within fetal membranes and of leukocytes (in amnion or chorion) was investigated (Fig. 7). The majority of preterm tissues were positive for organisms (in amnion or chorion) and for inflammatory cells, and the remainder were positive for either organisms or for inflammatory cells (single-positive tissues). Preterm labor and PPROM groups were similar to the preterm cesarean section group (Fig. 7), although the latter had fewer double-positive tissues. This indicated that the presence of bacteria in conjunction with inflammatory cells is not sufficient to cause preterm labor or PPROM. It would be premature to conclude that inflammatory cell infiltration can occur without bacteria, as organisms may be present in unsampled parts of the tissues.

In contrast, only a minority of term tissue were double positive (Fig. 7), but significant numbers of tissues were single positive, and some term tissues were negative for both organisms and inflammatory cells. These findings in term tissues confirm that the presence of bacteria and inflammatory cells is not sufficient to cause labor at any gestational age and that other processes are required.

Presence of organisms and a systemic fetal inflammatory response. Having shown that an inflammatory response was present in the fetal membranes after preterm labor and PPROM, we then determined fetal cytokine levels to assess whether there was a systemic fetal inflammatory response (Table 2). Two proinflammatory cytokines (IL-1 $\beta$ and IL-6) were increased in association with labor, and the antiinflammatory IL-10 was decreased. The variability in fetal cytokine levels was such that only some of these differences reached statistical significance (see Table 2 for details), but overall it was clear that there was a systemic fetal inflammatory response associated with PPROM and with chorioamnionitis. However, there was no association of the systemic fetal inflammatory response with leukocytes detected by immunohistochemistry or with bacteria.

\section{CONCLUSIONS}

Our primary conclusion is that FISH is an appropriate method for the visualization of bacteria within fetal membranes. Intrauterine bacteria are far more common than ex- pected, but these organisms alone may not be sufficient to initiate preterm labor, PPROM. or a systemic fetal inflammatory response and other factors including the nature of the organisms and tissue responses must be involved.

\section{REFERENCES}

1. Kelly RW 1994 Pregnancy maintenance and parturition: the role of prostaglandin in manipulating the immune and inflammatory response. Endocr Rev 15:684-706

2. Kelly RW 1996 Inflammatory mediators and parturition. Rev Reprod 1:89-96

3. McLean M, Bisits A, Davies J, Woods R, Lowry P, Smith R 1995 A placental clock controlling the length of human pregnancy. Nat Med 1:460-463

4. Frenkel RA, Muguruma K, Johnston JM 1996 The biochemical role of plateletactivating factor in reproduction. Prog Lipid Res 35:155-168

5. Ruiz RJ 1998 Mechanisms of full-term and preterm labor: factors influencing uterine activity. J Obstet Gynecol Neonatal Nurs 27:652-660

6. Challis JRG 2000 Mechanism of parturition and preterm labor. Obstet Gynecol Surv 55:650-660

7. Challis JR, Lye SJ, Gibb W, Whittle W, Patel F, Alfaidy N 2001 Understanding preterm labor. Ann NY Acad Sci 943:225-234

8. Minkoff H 1983 Prematurity: infection as an etiologic factor. Obstet Gynecol 62:137-144

9. Hillier SL, Witkin SS, Krohn MA, Watts DH, Kiviat NB, Eschenbach DA 1993 The relationship of amniotic fluid cytokines and preterm delivery, amniotic fluid infection, histologic chorioamnionitis, and chorioamnion infection. Obstet Gynaecol 81:941948

10. Benirschke K, Kaufmann P (eds) 2000 Pathology of the Human Placenta, 4th Ed. Springer-Verlag, New York, pp 591-608

11. Steinborn A, Gunes H, Roddiger S, Halberstadt E 1996 Elevated placental cytokine release, a process associated with preterm labor in the absence of intrauterine infection. Obstet Gynecol 88:534-539

12. Roos PJ, Malan AF, Woods DL, Botha P, Hyland J, Heese HdeV 1980 The bacteriological environment of preterm infants. S Afr Med J 57:347-350

13. Dong Y, St Clair PJ, Ramzy I, Kagan-Hallet KS, Gibbs RS 1987 A microbiologic and clinical study of placental inflammation at term. Obstet Gynecol 70:175-182

14. Romero R, Sirtori M, Oyarzun E, Avila C, Mazor M, Callahan R, Sabo V, Athanassiadis AP, Hobbins JC 1989 Infection and labor. V. Prevalence, microbiology, and clinical significance of intraamniotic infection in women with preterm labor and intact membranes. Am J Obstet Gynaecol 161:817-824

15. Lewis JF, Johnson P, Miller P 1976 Evaluation of amniotic fluid for aerobic and anaerobic bacteria. Am J Clin Pathol 65:58-63

16. Woods DL, Sinclair-Smith CC, Malan AF, Harrison A 1978 Amniotic fluid infection at term. S Afr Med J 53:137-139

17. Gibbs RS, Blanco JD, St Clair PJ, Castaneda YS 1982 Quantitative bacteriology of amniotic fluid from women with clinical intraamniotic infection at term. J Infect Dis $145: 1-8$

18. Romero R, Mazor M, Morrotti R, Avila C, Oyarzun E, Insunza A, Parra M, Behnke E, Montiel F, Cassell GH 1992 Infection and labor. VII. Microbial invasion of the amniotic cavity in spontaneous rupture of membranes at term. Am J Obstet Gynecol 166:129-133

19. Oyarzún E, Yamamoto M, Kato S, Gomez R, Lizama L, Moenne A 1998 Specific detection of 16 micro-organisms in amniotic fluid by polymerase chain reaction and its correlation with preterm delivery occurrence. Am J Obstet Gynecol 179:11151119

20. Krimmer V, Merkert H, Von Eiff C, Frosch M, Eulert J, Lohr JF, Hacker J, Ziebuhr W 1999 Detection of Staphylococcus aureus and Staphylococcus epidermidis in clinical samples by $16 \mathrm{~S}$ rRNA-directed in situ hybridization. J Clin Microbiol 37:2667-2673

21. Brand BC, Amann RI, Steinert M, Grimm D, Hacker J 2000 Identification and in situ detection of intracellular bacteria in the environment. Subcell Biochem 33:601-624

22. Licht TR, Krogfelt KA, Cohen PS, Poulsen LK, Urbance J, Molin S 1996 Role of lipopolysaccharide in colonization of the mouse intestine by Salmonella typhimurium studied by in situ hybridization. Infect Immun 64:3811-3817

23. Park CS, Kim J 1999 Rapid and easy detection of Helicobacter pylori by in situ hybridization. J Korean Med Sci 14:15-20

24. Schultsz C, Van Den Berg FM, Ten Kate FW, Tytgat GN, Dankert J 1999 The intestinal mucus layer from patients with inflammatory bowel disease harbors high numbers of bacteria compared with controls. Gastroenterology 117:1089-1097

25. Greig PC 1998 The diagnosis of intrauterine infection in women with preterm premature rupture of the membranes (PPROM). Clin Obstet Gynecol 41:849-863

26. Maymon E, Romero R, Pacora P, Gomez R, Mazor M, Edwin S, Chaiworapongsa T, Kim JC, Yoon BH, Menon R, Fortunato S, Berry SM 2001 A role for the $72 \mathrm{kDa}$ gelatinase (MMP-2) and its inhibitor (TIMP-2) in human parturition, premature rupture of membranes and intraamniotic infection. J Perinat Med 29:308-316

27. Greisen K, Loeffelholz M, Purohit A, Leong D 1994 PCR primers and probes for the $16 \mathrm{~S}$ rRNA gene of most species of pathogenic bacteria, including bacteria found in cerebrospinal fluid. J Clin Microbiol 32:335-351

28. Hay PE, Morgan DJ, Ison CA, Bhide SA, Romney M, McKenzie P, Pearson J, Lamont RF, Taylor-Robinson D 1994 A longitudinal study of bacterial vaginosis during pregnancy. Br J Obstet Gynaecol 101:1048-1053

29. Meis PJ, Goldenberg RL, Mercer B, Moawad A, Das A, McNellis D, Johnson F, Iams JD, Thom E, Andrews WW 1995 The preterm prediction study: significance of 
vaginal infections. National Institute of Child Health and Human Development Maternal-Fetal Medicine Units Network. Am J Obstet Gynecol 173:1231-1235

30. Sobel JD 2000 Bacterial vaginosis. Annu Rev Med 51:349-356

31. Evaldson GR, Malmborg A-S, Nord CE 1982 Premature rupture of the membranes and ascending infection. Br J Obstet Gynaecol 89:793-801

32. McGregor JA, French JI, Parker R, Draper D, Patterson E, Jones W, Thorsgard K, McFee J 1995 Prevention of premature birth by screening and treatment for common genital tract infections: results of a prospective controlled evaluation. Am J Obstet Gynecol 173:157-167

33. Kimberlin DF, Andrews WW 1998 Bacterial vaginosis: association with adverse pregnancy outcome. Semin Perinatol 22:242-250

34. Pankuch GA, Appelbaum PC, Lorenz RP, Botti JJ, Schachter J, Naeye RL 1984 Placental microbiology and histology and the pathogenesis of chorioamnionitis. Obstet Gynecol 64:802-806

35. Zlatnik FJ, Gellhaus TM, Benda JA, Koontz FP, Burmeister LF 1990 Histological chorioamnionitis, microbial infection, and prematurity. Obstet Gynecol 76:355-359

36. Osman I, Young A, Ledingham MA, Thomson AJ, Jordan F, Greer IA, Norman JE 2003 Leukocyte density and pro-inflammatory cytokine expression in human fetal membranes, decidua, cervix and myometrium before and during labour at term. Mol Hum Reprod 9:41-45

37. Vince GS, Starkey PM, Jackson MC, Sargent IL, Redman CW 1990 Flow cytometric characterisation of cell populations in human pregnancy decidua and isolation of decidual macrophages. J Immunol Methods 132:181-189

38. Sacks GP, Studena K, Sargent K, Redman CW 1998 Normal pregnancy and preeclampsia both produce inflammatory changes in peripheral blood leukocytes akin to those of sepsis. Am J Obstet Gynecol 179:80-86

39. Redman CW, Sacks GP, Sargent IL 1999 Preeclampsia: an excessive maternal inflammatory response to pregnancy. Am J Obstet Gynecol 180:499-506

40. Mellembakken JR, Aukrust P, Olafsen MK, Ueland T, Hestdal K, Videm V 2002 Activation of leukocytes during the uteroplacental passage in preeclampsia. Hypertension 39:155-160

41. Campbell S, Swann HR, Seif MW, Kimber SJ, Aplin JD 1995 Cell adhesion molecules on the oocyte and preimplantation human embryo. Hum Reprod 10:1571-1578
42. Burrows TD, King A, Loke YW 1994 Expression of adhesion molecules by endovascular trophoblast and decidual endothelial cells: implications for vascular invasion during implantation. Placenta 15:21-33

43. Proll J, Blaschitz A, Hartmann M, Thalhamer J, Dohr G 1996 Human first-trimester placenta intra-arterial trophoblast cells express the neural cell adhesion molecule. Early Pregnancy 2:271-275

44. Jarousseau AC, Thibault G, Reverdiau P, Rodriguez AM, Lacord M, de Russe J, Watier H, Degenne D, Lebranchu Y, Gruel Y, Le Bouteiller P, Bardos P 1994 Adhesive properties of choriocarcinoma cells toward lymphocytes activated or not by interleukin-2. Cell Immunol 157:38-47

45. Kimber SJ, Bentley J, Ciemerych M, Moller CJ, Bock E 1994 Expression of N-CAM in fertilized pre- and periimplantation and parthenogenetically activated mouse embryos. Eur J Cell Biol 63:102-113

46. Blankenship TN, King BF 1996 Macaque intra-arterial trophoblast and extravillous trophoblast of the cell columns and cytotrophoblastic shell express neural cell adhesion molecule (NCAM). Anat Rec 245:525-531

47. Potgens AJ, Gaus G, Frank HG, Kaufmann P 2001 Characterization of trophoblast cell isolations by a modified flow cytometry assay. Placenta 22:251-255

48. King A, Balendran N, Wooding P, Carter NP, Loke YW 1991 CD3- leukocytes present in the human uterus during early placentation: phenotypic and morphologic characterization of the CD56++ population. Dev Immunol 1:169-190

49. Le-Barillec K, Si-Tahar M, Balloy V, Chignard M 1999 Proteolysis of monocyte CD14 by human leukocyte elastase inhibits lipopolysaccharide-mediated cell activation. J Clin Invest 103:1039-1046

50. Le-Barillec K, Pidard D, Balloy V, Chignard M 2000 Human neutrophil cathepsin G down-regulates LPS-mediated monocyte activation through CD14 proteolysis. J Leukoc Biol 68:209-215

51. Matsubara S, Yamada T, Minakami H, Watanabe T, Takizawa T, Sato I 1999 Polymorphonuclear leukocytes in the fetal membranes are activated in patients with preterm delivery: ultrastructural and enzyme-histochemical evidence. Placenta 20:185-188 